\title{
SZINKRON VÁLTAKOZÓ ÁRAMÚ HIDRAULIKUS HAJTÁS PARAMÉTEREINEK VIZSGÁLATA
}

\author{
Fekete Tamás \\ tanársegéd, Miskolci Egyetem, Szerszámgépészeti és Mechatronikai Intézet, Szerszámgépek Intézeti Tanszéke \\ 3515 Miskolc, Miskolc-Egyetemváros, e-mail: fekete@uni-miskolc.hu
}

\begin{abstract}
Absztrakt
A váltakozó áramú hajtásoknál a fázisvezetékekben lévő olaj alternáló mozgást végez. A váltakozó áramú hidraulikus hajtás egyik elönye az egyenáramú hajtással szemben, hogy nagyméretü tartályra nincs szükség. A pulzáló folyadékáramot egy központi hidrogenerátor állitja elö, és a pulzáló folyadékárammal az adott berendezésen lévö hidromotorok a meghajtása kivitelezhetö külön-külön vagy együttesen is. Az adott körülményeket figyelembe véve meg kell vizsgálni, hogy melyik hajtást érdemes választani a kitüzött célra. Ebben a dolgozatban erre a kérdésre próbálunk választ adni.
\end{abstract}

Kulcsszavak: váltakozó áramú hidraulikus hajtás, hidromotor, hidrogenerátor

\section{Abstract}

The energy transfer at the hydraulic drives can be solving with direct current hydraulic drives and alternating current hydraulic drives. At the direct current hydraulic drives, the operating fluid flow in one way besides the alternating current hydraulic drives where it alternating periodically between the hydro generator and the hydraulic motor. Depending on the circumstances, it should be considered which drive is best for the intended purpose. In this paper we try to answer this question.

Keywords: direct current hydraulic drive, hydraulic motor, hydro generator

\section{Bevezetés}

Mind a forgalomban mind a technika egyéb területén felhasznált jármüveknél, munkagépeknél (nem kötött pályán közlekedő) alapvető probléma az irányíthatóságának-kormányozhatóságának kialakítása és a mozgó berendezéseinek müködtetéséhez szükséges meghajtásának megtervezése. A hajtások megvalósítása történhet mechanikus, villamos, pneumatikus és hidraulikus energia felhasználásával is. A felsorolt technikával müködtetett hajtások közül a hidraulikus hajtásokkal foglalkozom, és egy olyan hajtást szeretnék bemutatni, amit a jármüiparban hajtástechnikai feladatokra fel lehetne használni. A villamos analógia szerint a hidraulikus hajtásokat két fó csoportra bonthatjuk: az egyenáramú hidraulikus hajtásokra és váltakozó áramú hidraulikus hajtásokra.

Az egyenáramú hidraulikus hajtásoknál a szivattyú és a motor(ok) között az energiaközvetítő közeg (pl. olaj) egyirányú mozgást végez. Az egyenáramú hidraulikus hajtásoknál a hidraulikus ellenállások miatt jelentős a hőfejlődés, és ezt a hőfejlődést a rendszerből el kell vezetni. A keletkezett hő elvezetését hőcserélőkkel vagy nagyméretü olajtartályokkal lehet megvalósítani.

A váltakozó áramú hajtásoknál fázisvezetékekben lévő olaj alternáló mozgást végez, ezért a hődisszipáció kisebb, mert az alternáló mozgás miatt nem tud kialakulni a parabolikus sebességeloszlás a 
fázisvezetékekben. A váltakozó áramú hajtások két csoportra bonthatóak: szinkron és nem szinkron (és aszinkron). Most be szeretném mutatni, egy általam készített kísérleti szinkron váltakozó áramú hidraulikus hajtást.

A váltakozó áramú hidraulikus hajtásnak (1. ábra) három fỏ változata van, a szinkron (A-VAH), a nem szinkron és az aszinkron. A váltakozó áramú hidraulikus hajtásnak három fó építési egysége, a hidrogenerátor (VHG) a hidromotor (VHM) és a fázistér (fázisvezetékek). A VHG bemenő tengelyének meghajtásáról egy egyenáramú hidromotor gondoskodott. A megoldás előnye, hogy a VHM fordulatszámának fokozatmentes változtatása valósítható meg frekvencia-szabályozással. A berendezés amplitúdó szabályozása kettős excenterrel valósítható meg.

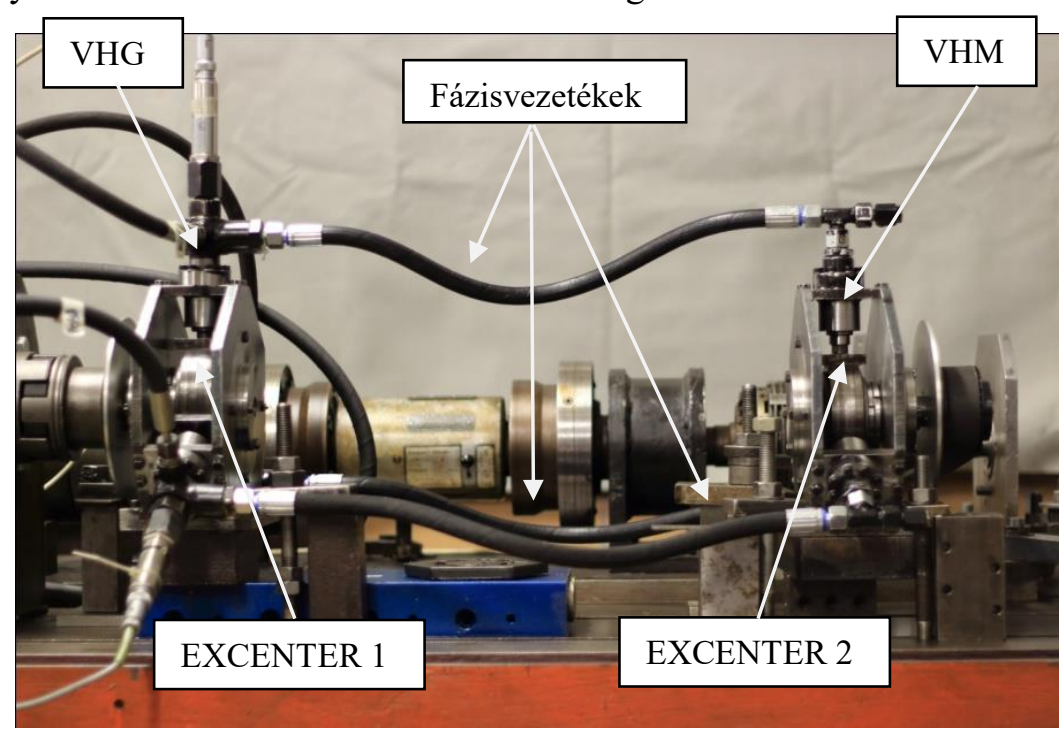

1. ábra. A kisérleti váltakozó áramú szinkron rendszerü hidraulikus hajtás (S-VAH).

A kísérleti berendezés sematikus ábráját a 2. ábra mutatja.

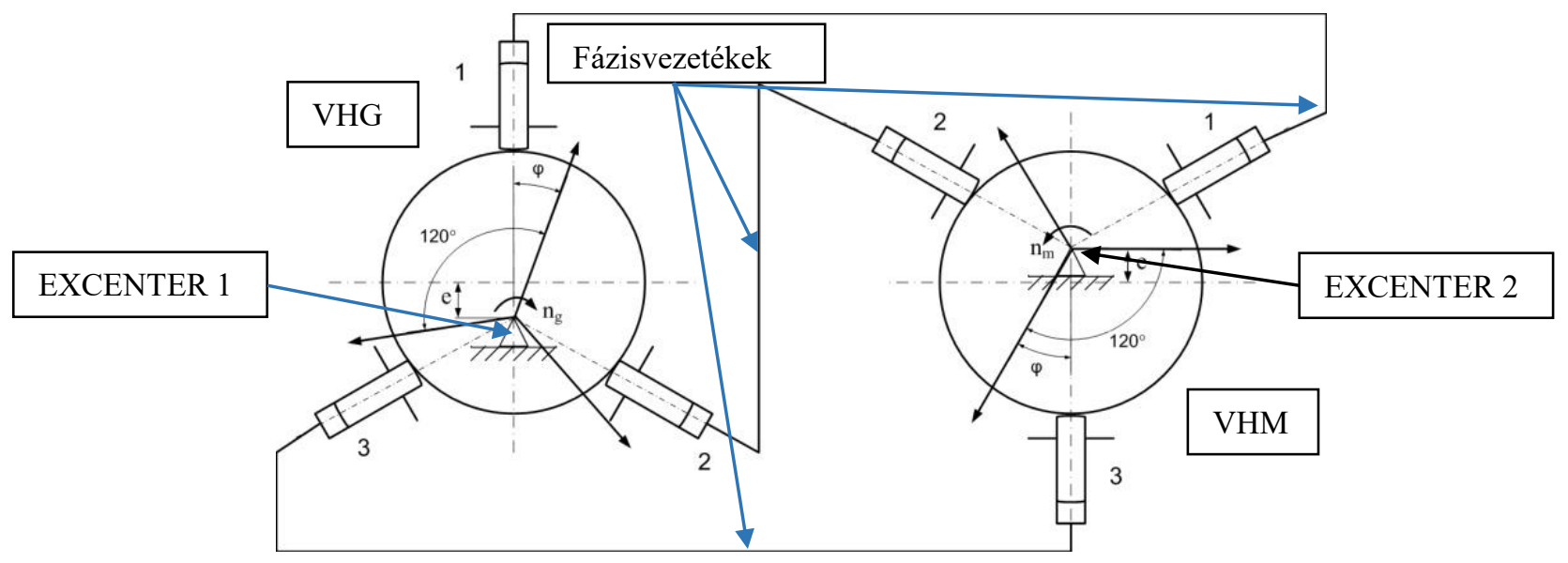

2. ábra. A szinkron rendszerü váltakozó áramú kísérleti berendezés sematikus ábrája (S-VAH). 


\section{A szinkron rendszerü váltakozó áramú hidraulikus hajtás (S-VAH)}

A váltakozó áramú hidraulikus hajtás egyik előnye az egyenáramú hajtással szemben, hogy nagyméretü tartályra nincs szükség. A pulzáló folyadékáramot egy központi hidrogenerátor (VHG) állítja elő (3. ábra), és a pulzáló folyadékárammal az adott berendezésen lévő hidromotorok (VHM) meghajtása kivitelezhető külön-külön vagy együttesen is. A hidrogenerátor meghajtása külső hajtással történik, ami lehet villanymotoros, benzin vagy dízel üzemü belső égésủ motoros, vagy hidromotoros is. Jelen eseteben a meghajtás egyenáramú hidromotorral történik.

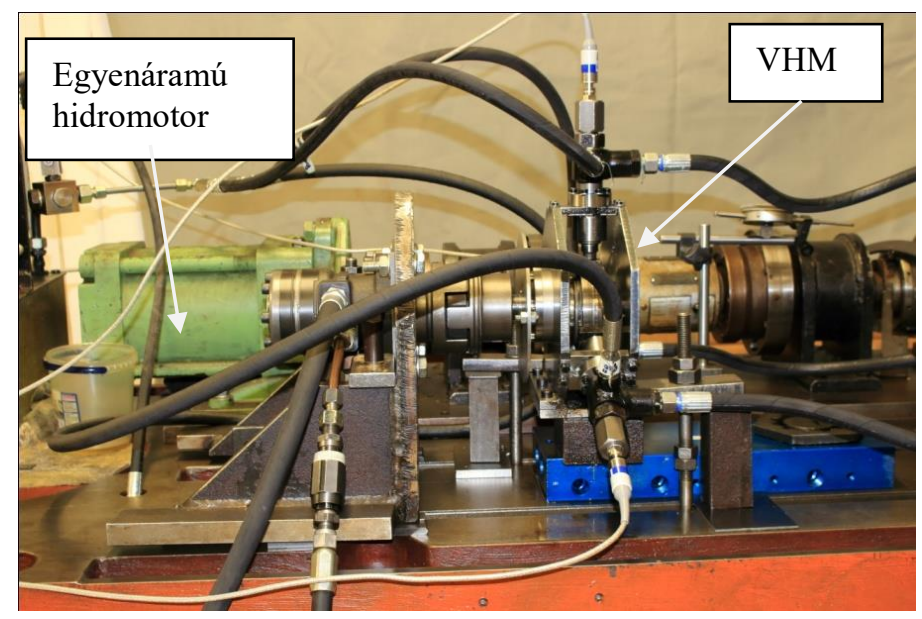

3. ábra. A központi hidrogenerátor meghajtása.

A generátor az energiaátvitel láncban az energiaforrás szerepét tölti be. A generátor fö részei a fázishengerek, a bennük lévő fázisdugattyúk és a fázisdugattyúkat mozgató mechanizmus. Ezek együttese biztosítja a hidraulikus szakaszok gerjesztését, melynek eredménye a folyadékáram. Szinkron hajtás esetén a VHG és a VHM kialakítása azonos felépítésủ. A 4. ábrán láthatjuk a hidromotort a terhelömodullal.

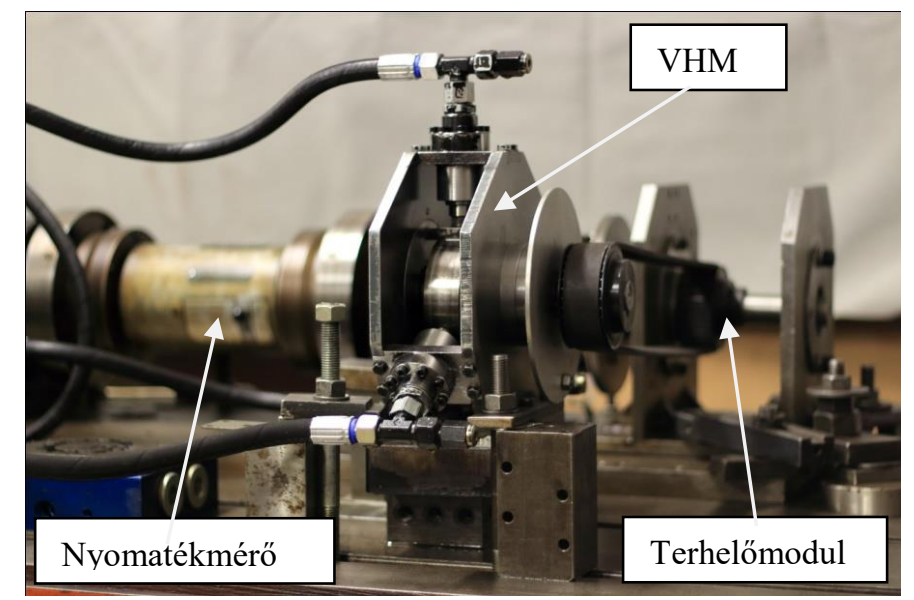

4. ábra. A szinkron váltakozó áramú hidraulikus hajtás hidromotorja (VHM) a terhelömodullal. 
Az excenter mozgástörvényének ismeretéből meghatározható a dugattyúk mozgása. Vizsgáljuk meg az excenter mozgását és azt, hogy ez milyen hatással van a dugattyúk mozgására. Az 5. ábra alapján meghatározható, hogy a $\rho$ értéke milyen összefüggésben van a $\varphi$ szög megváltoztatásával.

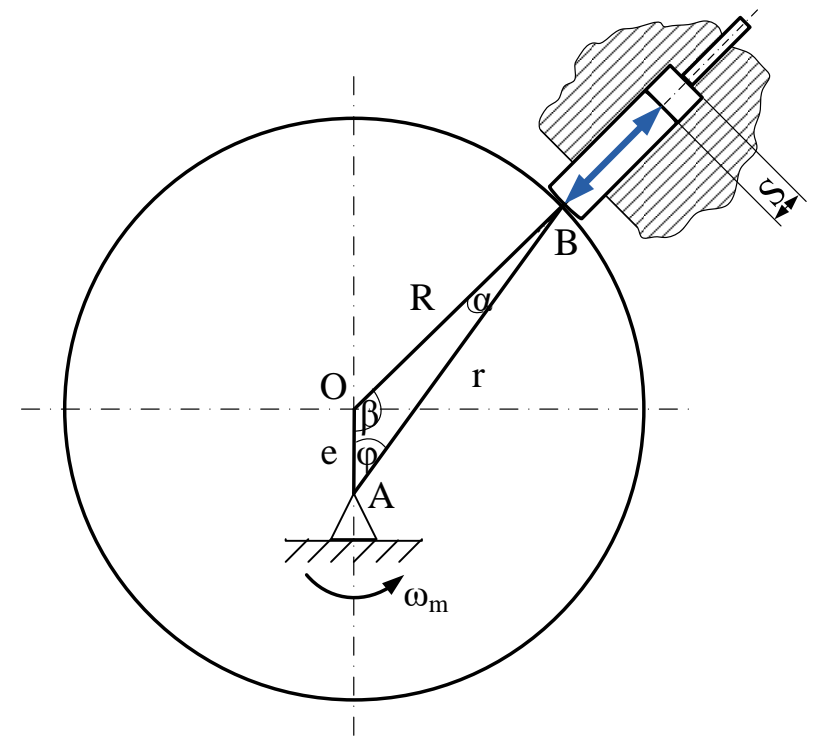

5. ábra. Az excenter mozgásának hatása a dugattyú elmozdulására.

A dugattyú és a kettős excenter érintkezési pontja, illetve a kettős excenter forgási középpontjára felírhatók a következö összefüggések.

$\mathrm{Az}(O A B)$ háromszögre felírható:

$$
\frac{e}{R}=\frac{\sin \alpha}{\sin \phi} ; \beta=180^{\circ}-\alpha-\phi ; \alpha=\arcsin \left(\frac{e}{R} \sin \phi\right) .
$$

Koszinusz tétel alkalmazásával:

$$
\begin{gathered}
r^{2}=R^{2}+e^{2}-2 \cdot R \cdot e \cdot \cos \beta \\
r^{2}=R^{2}+e^{2}-2 \cdot R \cdot e \cdot \cos \left(\pi-\arcsin \left(\frac{e}{R} \sin \phi\right)-\phi\right)
\end{gathered}
$$

Vezessük be $\lambda$ változót, ami a tárcsa sugara $R$ és az excentricitás $e$ hányadosa:

$$
\begin{gathered}
\lambda=\frac{e}{R} \rightarrow e=\lambda R \\
r^{2}=R^{2}+e^{2}+2 \cdot R \cdot e \cdot \cos \phi=R^{2}+\lambda^{2} R^{2}+2 \cdot R^{2} \cdot \lambda \cdot \cos \phi \\
\rho^{2}=2 \cdot R \cdot e \cdot \cos \phi+e^{2} \cos ^{2} \phi+e^{2} \sin ^{2} \phi
\end{gathered}
$$

a fázisdugattyú mozgástörvénye az átalakítások után:

$$
r=R+e \cos \phi
$$

Háromfázisú rendszer esetén a fázisterek egymáshoz képest $120^{\circ}$-ra helyezkednek el, így:

$$
r_{i}(\phi)=R+e \cos \left(\phi+(i-1) \frac{2 \pi}{3}\right), i=1 \ldots 3 .
$$


A (8) egyenlet alapján a fázisdugattyúk elmozdulása:

$$
s_{i}(\phi)=e-e \cdot \cos \left(\omega t+(i-1) \frac{2 \pi}{3}\right), i=1 \ldots 3,
$$

adódik, majd rendezve a (9) egyenleteket:

$$
s_{i}(\phi)=e\left[1-\cos \left(\omega t+(i-1) \frac{2 \pi}{3}\right)\right], i=1 \ldots 3 .
$$

A váltakozó áramú hidraulikus hajtást üresjárásban is érik terhelések. Ezek a terhelések a már elözőekben megemlített és részletesebben megtárgyalt ohmos, induktív és kapacitív hidraulikus ellenállások. Az egyszerübb tárgyalásmód kedvéért most ezektől tekintsünk el.

A szakirodalom az egyenáramú hidraulikus hajtások elemzésére rövid csőhosszak esetén alkalmazza a villamos analógiát. Ez kiterjeszthető a hidraulikus váltakozó folyadékáramra is. Az így kapott analóg összefüggések alkalmasak a váltakozó áramú hidraulikus rendszerek átviteli tulajdonságának vizsgálatára. A VHG által előállított folyadékáramok jelleggörbéje, jó közelítéssel szinuszos, $\tilde{Q}_{i}(i=1,2,3)$ fázis folyadékáramok az alábbi összefüggéssel számíthatók:

$$
Q_{i}=Q_{0} \cdot \sin \left(\omega t+k \cdot \frac{2 \pi}{3}\right)
$$

ahol, a folyadék áram abszolút értéke

$$
Q_{0}=A \cdot e \cdot \omega_{g}
$$

ahol:

$A$ a dugattyúvég felülete $\left(\mathrm{m}^{2}\right)$,

$e$ az excentricitás (m),

$\omega_{g}$ a generátor szögsebessége $(1 / \mathrm{s})$.

A három hidraulikus hengerteret:

$$
x_{g_{i}}=r \cos \left(\omega t-(i-1) \frac{2 \pi}{3}\right), i=1 \ldots 3
$$

mozgástörvényü, egyforma homlokfelületü dugattyúkkal gerjesztünk. A

$$
\varphi_{h_{1}}=L_{h_{1}} Q_{1}
$$

ahol

$\varphi_{h}$ a hidraulikus fluxus,

$L_{h}$ a hidraulikus indukciós tényező,

$Q$ a térfogatáram ill. folyadékáram,

és

összefüggésekből

$$
\varphi_{h_{1}}=\frac{m}{A^{2}} \frac{d x_{g l}}{d t}
$$

$$
L_{h}=\frac{m}{A^{2}}
$$

helyettesítéssel a $Q_{1}$ folyadékáram meghatározható: 
Hasonlóan:

$$
Q_{1}=-A r \sin \omega t
$$

$$
Q_{2}=-\operatorname{Ar} \sin \left(\omega t-\frac{2 \pi}{3}\right)
$$

és

$$
Q_{3}=-\operatorname{Arsin}\left(\omega t-\frac{4 \pi}{3}\right)
$$

A három folyadékáram összegét képezve:

$$
Q_{1}+Q_{2}+Q_{3}=0
$$

adódik. Ez teszi lehetővé az összekötő csővezetékek számának csökkentését. A rendszer müködésének elengedhetetlen feltétele, hogy a három folyadékáram összege zérus legyen $\left(\sum Q=0\right)$. Ha e feltétel nem teljesül, akkor a fázisvezetékekben nyomásnövekedés lép fel.

\section{Mérések}

A kísérleti méréseket az 1. ábrán látható rugalmas tömlőkkel felszerelt egységen végeztük. A rugalmas tömlők előnye, hogy a hajtás tetszőleges úton továbbítható, hátránya, hogy a rendszer kapacitív jellege nő, így a hajtó teljesítmény csökken. A mérések célja, hogy alaposan megismerjük a szinkron váltakozó áramú hidraulikus hajtás (S-VAH) átviteli tulajdonságait, elméleti nyomaték és fordulatszám karakterisztikák összefüggéseit. A mérőmüszerek elrendezését a 6 . ábra mutatja.

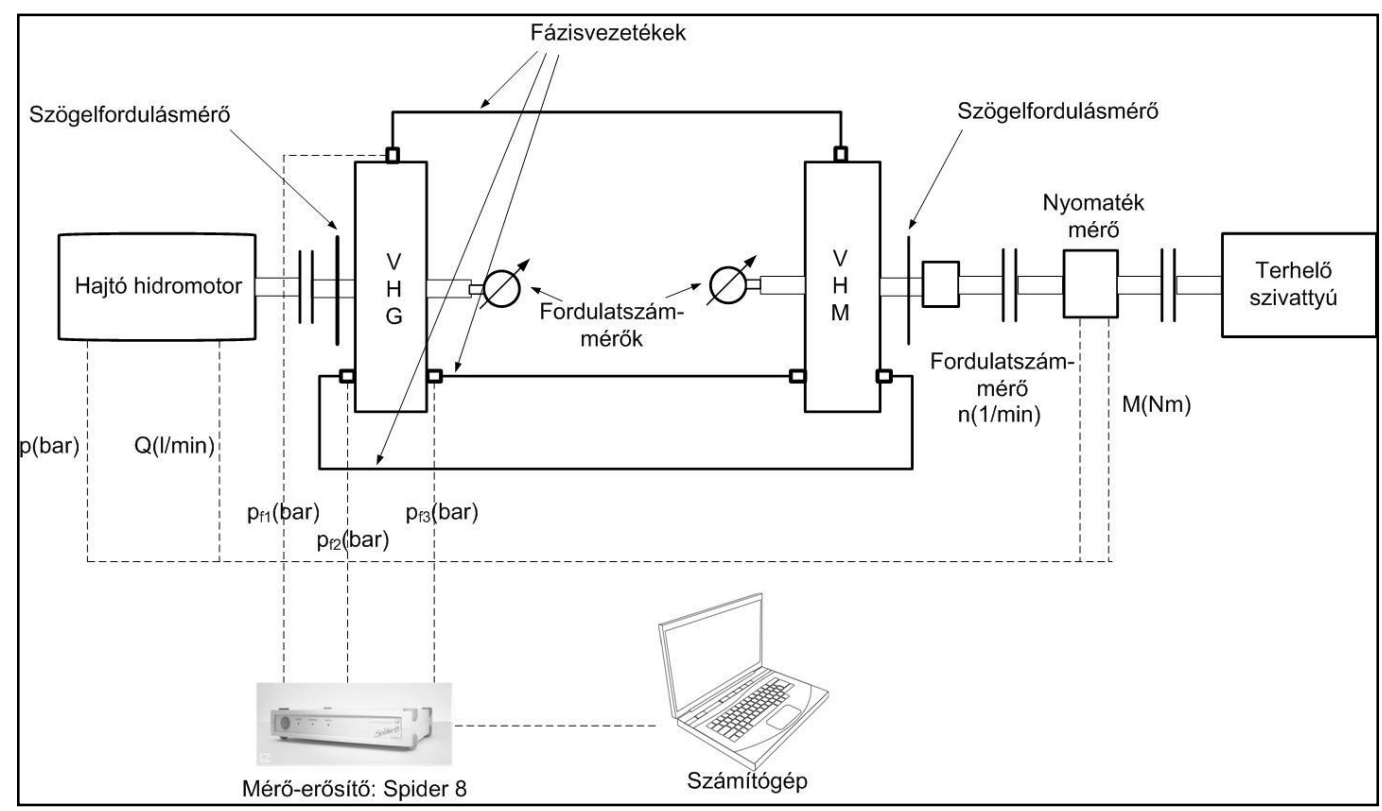

6. ábra. A mérési elrendezés.

A fenti mérés összeállítással meghatározhatjuk a hajtóművek fontosabb jellemzőit, a hidromotor fordulatszámát és terhelhetőségét, illetve ezek összefüggéseit a megfelelő mérőmüszerek segítségével. 


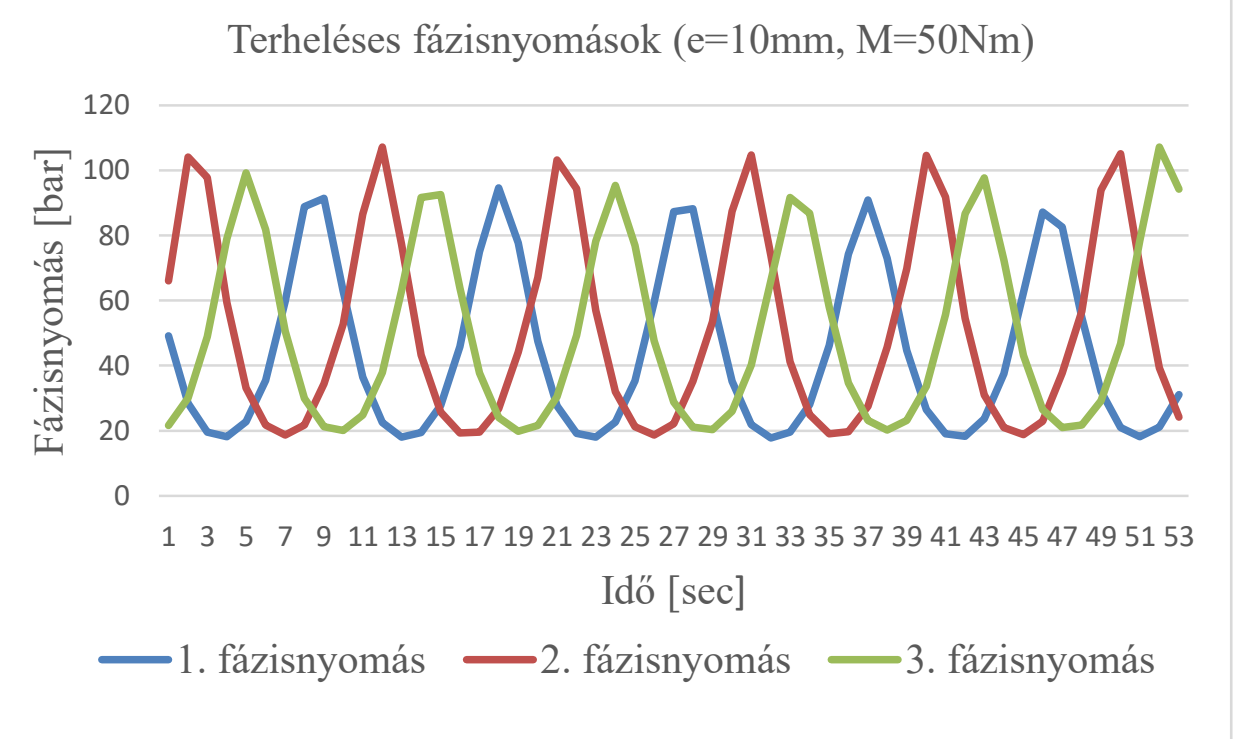

7. ábra. A nyomásértékek alakulása maximális terhelés hatására rugalmas fázisvezetékekkel.

\section{4. Összefoglalás}

A bemutatásra került dolgozatból következtethető, hogy a váltakozó áramú hajtás alkalmas hajtási feladatok ellátására. Ennek a technikának a fejlesztési lehetősége, hogy a generátor fordulatszámának állíthatóságát a modern elektrotechnikát felhasználva valósítsuk meg. Későbbiekben célszerü még a hőhatások alaposabb vizsgálata.

\section{Köszönetnyilvánítás}

A cikkben/előadásban/tanulmányban ismertetett kutató munka az EFOP-3.6.1-16-2016-00011 jelü „Fiatalodó és Megújuló Egyetem - Innovatív Tudásváros - a Miskolci Egyetem intelligens szakosodást szolgáló intézményi fejlesztése" projekt részeként - a Széchenyi 2020 keretében - az Európai Unió támogatásával, az Európai Szociális Alap társfinanszírozásával valósul meg.

\section{Irodalom}

[1] Fekete,T.: The alternating current synchronous hydraulic drive. Annals of Faculty of Engineering Hunedoara - International Journal of Engineering 12: pp. 235-238. (2014)

[2] Pattantyús, Á.G.: Gyakorlati áramlástan, Budapest, Tankönyvkiadó 1951.

[3] Ponomarjov, Sz.D.: Szilárdsági számítások a gépészetben c. kötet. Rezgések Ütések. Budapest, Müszaki Könyvkiadó 1966.

[4] Erdélyi, J., Fekete, T., Lukács, J.: A kontrakciós henger konstrukciós és müködési tulajdonságai. (p.3-5) Pneumatika, hidraulika, hajtástechnika, automatizálás XII. évf. 2008. 